\title{
The Integration of ICT in ELT Practices: The Study on Teachers' Perspective in New Normal Era
}

\author{
https://doi.org/10.3991/ijim.v15i22.25533 \\ Mister Gidion Maru ${ }^{(凶)}$, Chris Caesar Pikirang, Donal M Ratu, Jim Ronny Tuna \\ Universitas Negeri Manado, Manado, Indonesia \\ mrgidionmaru@unima.ac.id
}

\begin{abstract}
The emergence of the Covid-19 Pandemic has defined more dependence upon the involvement of ICT in EFL Class. This study investigates the integration of ICT in English teaching practices among teachers in the EFL context in a new normal setting. To achieve the aim of the study, a mixed-method approach has been applied. Thirty-two EFL teachers of junior high school who joined as members of Musyarawah Guru Mata Pelajaran (MGMP-English Teacher Regional Forum) in Bitung City, North Sulawesi, Indonesia. They have been selected as the participants for their familiarity for teaching English using the technological tools and for their teaching experience. A quantitative inquiry is carried out by distributing a questionnaire of twenty-three items adapted from two questionnaires namely those of Mailizar \& Fan, and Almalki. Due to the Pandemic, the questionnaires are distributed by utilizing Google form, and then, the responses are analyzed by using SPSS tool. The qualitative data are in the forms of interview as the verification to deepen the discussion of the quantitative results. The semi-structured interview is performed and the responses are analyzed in triangulation method. The study showed that teachers' knowledge and perception toward the integration of ICT is high. Further, this study found that despite acknowledging the importance of the enjoyment of integrating the ICT in the learning process, teachers identified the aspects of learners' lack of technological literacy and infrastructure, and lack of motivation can be barriers for the success of the ICT integration. For such challenges, the study also revealed that teachers attempt to practice a sort of home visit and invitation learning and encouraging the making of soft skills for class activity management. These findings expectedly contribute to define the role of ICT in the current pandemic era.
\end{abstract}

Keywords—-teachers' perspective, ICT integration, new normal era

\section{$1 \quad$ Introduction}

ICT integration in the teaching-learning process has become a new trend during the COVID-19 outbreak until now at the new normal setting, especially in English Language Teaching (ELT) where most EFL teachers use it as the method in the learning 
process [1]. It includes the use of the internet, gadget, computer with different applications and software. In Indonesia, it has become an essential method from March until now in September to progress teaching practices, to conduct online meetings, etc. More particularly in the local area such as Bitung city, North Sulawesi. Before it, the use of ICT in the teaching-learning process was not as intensive as it was. Teachers commonly used the traditional method in their learning process even though has been directed by the national policies of Indonesia to start operating technology as a valuable aid in teaching practices [2]. But then, the use of technology in the learning process has rapidly grown and important [3] due to this current pandemic. The implementation of technology in education could help teachers to reach their learners globally with the help of video conferencing and also by having a virtual meeting. And if it is combined with effective teaching practices, a good learning environment would be created also their English skills would be enhanced over time [4], [5].

\section{Literature review}

\subsection{ELT practices in new normal setting}

The Indonesian governments had declared a health protocol for the community as the new ethics to be discerned in this new normal period from May until early November 2020. This declaration demands society to begin to apply a new behavior in surviving the pandemic, hence, communities were required to keep the social distancing between others, keep conducting learning/working from home, wearing face masks/face shield in public, and wash off their hands before and after holding the objects or done any activities in public; these preventive actions were compulsory as waiting for the vaccination availability [6]. These regulations, also, had impacted the teaching-learning process. Schools are now open occasionally to allow teachers to conduct teaching practices for those who do not possess smartphone/gadget or computer, indeed without disregarding the health protocol. While the rest of that, distance-learning or learning from home were put to good use as the solutions both for teachers and learners who have smartphones/gadgets/computers [7]. These programs were named Luring (Luar Jaringan) as appointed for those who learn traditionally; Daring (Dalam Jaringan) is addressed to those who learn digitally from home. Briefly, such practices are paramount in avoiding mass crowded groups in schools and to cut down the rapid spread of COVID-19.

\subsection{ICT integration in ELT practices}

ICT integration refers to how teachers operate and manage the technology to perform the learning process more engaging by keeping the authenticity of the material [8]. In other words, technology integration is the use of technology to enhance, to complete, and to aid the teaching-learning process. In the context of EFL class, According to Ahmadi [9] technology has become an essential tool in the English teaching-learning process due to its advantages for teachers and to support learners' learning progress. Which resulted in learners gained language skills and teachers gained knowledge along 
with self-efficacy. He also noted that while technology integration in the teaching-learning process is being applied, the class will become more active, attractive and learners are responsible for their progress which results in meaningful learning. He continued to state that technology gives learners a chance to be English autonomous learners in their learning which is good for their English language development.

Further, a study reported that learners' participation, IT skills, and willingness to learn autonomously and cooperatively were refined. Teachers also seem to develop a good sense of professionalism in their careers [10]. Again, a study showed that ICT integration could stimulate learners' motivation to be engaged in learning due to their customs in this $21^{\text {st }}$ to learn with technology [11], [12]. This could be true to assert that ICT integration merits both teachers and learners in the teaching-process as both parties taking part in the ICT learning methods. Much further, a study whose effort to replace the traditional method with Moodle-based e-learning has gained a positive impact. The learners enjoyed learning at their own pace, their English language skills were significantly improved compared to control groups, then it supported many advantages for teachers as it does provide a friendly unit interface that is easy to be understood [13].

In addition to that, a study that addressing the needs of millennial learners carried out the blended learning companied with Instagram as the platform in teaching [14]. Due to its potential in bringing millennial learners' attention, it was used as the platform for teachers to advance the English learning process, then, it is conducted to carry out learners' perceptions toward these practices. As a result, learners were showing positive acknowledgment of these practices due to their familiarity with the social networking site which is merits their willingness to learn the English language independently. They stated that such platforms could be used for academic purposes in supporting their learning progress. Next to it, blended learning using social media Instagram as the platform for teachers had gained positive results. A study [15] indicated that learners' critical thinking, listening to apprehension skills were showing a meaningful improvement. Moreover, their motivation also is high due to the social media-friendly interface and its swiftness to access the portal. Hence, ICT based learning nowadays is essential to be implemented as it merits both teachers and learners in this digital era.

\subsection{Teachers' knowledge toward ICT}

The original study of teachers' knowledge on pedagogical content was proposed by Shulman [16] (1986) then abbreviated as PCK (Pedagogical Content Knowledge). He identified it as awareness to combined, organized, and aligned different contents to match up with learners' learning ability in teaching-learning progress. Having this in mind, Koehler and Mishra [17] introduced TPCK (Technological Pedagogical Content Knowledge) as the extension of PCK, it represents how teachers would elaborate the multitude of technology for learning purposes [18]. It was then be compacted to TPACK (Technology, Pedagogy, and Content Knowledge) by Thompson and Mishra [19]. As they believed that the necessity for teachers to the technology literacy in operating, elaborating, and organizing the content material in their teaching methodology. Furthermore, Angeli and Valanides [20] adapted the TPACK into ICT-TPCK. They retitle the technical terms into Information and Communication Technology (ICT) along 
with some additional terms into the context. They advocated the five terms of literacy that is necessary for teachers who incorporating ICT in teaching practices: namely, content knowledge, the ability to sense the particular subject; pedagogical knowledge, the ability to manage the methodologies in teachings, such as classroom management, assessment, and lesson plan; knowledge of learners, it is the ability to get knowing their infants' need, skill and identity; knowledge of context, the comprehension of the use of various facilities and to adapt with it, and; knowledge of ICT, it is the endowment to function a hardware and software also the internet.

The previous study [21] adapted the original terms into ICT-Content Knowledge (ICT-CK), ICT- Pedagogical Knowledge (ICT-PK), and ICT-Pedagogical Content Knowledge (ICT-PCK), as the purpose was to seek the Indonesian teachers' knowledge of ICT in mathematics teaching. Consequently, the current study adapted the previous frame to the context of English Teaching Practices (ELT) then reframed the term as knowledge of the current technology, which represents their sense of the current devices; knowledge of platforms/LMS, which refers to how they can manage the platforms in teaching; knowledge of online tools; which refers to their ability in managing the online contents or applications. Subsequently, ICT-content knowledge, ICT-pedagogical knowledge, and ICT-pedagogical content knowledge were contextualized to align the purpose of the study.

\subsection{Barriers of ICT integration}

Although the usage of a technological learning environment had gained positive application, some challenges had been exclusively reported. Firstly, the external factors include inadequate source and access to the technology, and lack of support and practice which would affect teachers' development career professionalism. Secondly, the internal factors include teachers' acknowledgment, low self-efficacy, and lack of confidence [22]. Inadequate sources and access to the internet reflects the poor infrastructure is still the matter in this modern era. This is due to not all schools in the urban area, especially in the rural area, are bound to various types of technology [22]. The internet connection also the exposure to the multitudes of technology equipment still have limited access to the rural area. Particularly in this new normal, those who have no or lack access to the technology are encountering difficulties to conduct the teaching-learning process digitally. Therefore, it is reasonable why they still kept traditional methods of teaching. Not only that, studies report that poor digital equipment, inadequate number of computer labs, illiterate to operate particular software and hardware, and lack of technical supports are some major barriers claimed by educators, learners, and institutions [23], [24]. Hence, it disrupts the effectiveness of ICT integration [25].

Apart from the external factors, however, internal factors hold crucial barriers to integrate technology in teaching, as well. The factors namely, lack of knowledge, negative attitudes, negative perceptions, bad experiences, negative beliefs, and other technical problems concerned as the internal barriers for instructors [26], [27]. Additionally, it is found that teachers seem to have technical knowledge but may not have sufficient understanding to operate, elaborate various teaching contents into pedagogical practices for ELT [28]. Such conditions would affect their self-confidence also self-efficacy then turns out to disregard the essentials of ICT integration in the learning process [29]. Others, however, are unwilling to integrate technology into their teachings style due to 
lack of interest and limited time to manage the materials; due to unfamiliarity accompanied with the lack of knowledge to the technology which restrains them to get in contact with technology which resulted in high dependence on traditional teaching styles [30]. Those conditions would likely be minimized if they have been equipped with suitable ICT literacy in which could help them be more enjoyable and comfortable to integrate technology in their teachings methodologies. Noted this, the study designed to investigate the current knowledge of EFL teachers of ICT and their perceptions toward ICT integration in online learning in the new normal setting.

\section{$3 \quad$ Research methodology}

The mixed research methods had been utilized in the current study. This study was meant to seek teachers' knowledge and perceptions of the use of ICT in online learning in this new normal setting through the questionnaires. A deeper, group interview was applied to support the quantitative data. Teachers' perspectives toward ICT in online learning in a new normal context were explored through the interview. Two questionnaires adapted from reference [21] and reference [1] were applied in this study. 23 items have been selected and adapted purposely for this context of the study, further, all the responses to the item were coded in a five-point scale, ranging from $1=$ strongly disagree to $5=$ strongly agree. The validity of the questionnaire had been qualified by the expert of the University State of Manado and was clearly stated well to proceed further.

The distributed data had successfully been collected through Google Form online for the reason of obeying the health protocol. The respondents of the study were EFL teachers of junior high school in Bitung City who were included in the MGMP (Musyawarah Guru Mata Pelajaran Bahasa Inggris_-English Teacher Regional Forum in Bitung). The total number of participants were 32 teachers. The participants' age, cultural background and financial background will not be counted in as the study not cover it. However, they were purposely selected as they have been familiar with the ICT integration in online learning condition, plus, have been experienced directly the nuances of teaching in new normal settings.

The collected data were analyzed by the SPSS tool. Teachers' knowledge of ICT learning was described descriptively using the mean score range to answer their knowledge level. The listed criteria were displayed in Table 1 reference [21].

Table 1. Questionnaire score range

\begin{tabular}{|c|l|}
\hline Score Range & \multicolumn{1}{c|}{ Score Range } \\
\hline $1.0-1.5$ & Very low \\
\hline $1.6-2.0$ & Low \\
\hline $2.1-2.5$ & Moderately Low \\
\hline $2.6-3.0$ & Slightly below average \\
\hline 3.0 & Average \\
\hline $3.1-3.5$ & Slightly above average \\
\hline $3.6-4.0$ & Moderately high \\
\hline $4.1-4.5$ & High \\
\hline $4.6-5.0$ & Very high \\
\hline & \\
\hline
\end{tabular}


The teachers' perception toward ICT learning data was also analyzed descriptively using numerical calculation of the percentages. The formula used to calculate the percentage of collected data as follows.

$$
\text { Percentage }=\frac{\text { Total score obtained }}{\text { Maximum Score }} \times 100 \%
$$

To classify the teachers' perception level on the integration of ICT in online learning in new normal settings, Table 2 represents the criteria of perception used [31].

Table 2. Criteria of perception

\begin{tabular}{|c|l|}
\hline Percentage & \multicolumn{1}{c|}{ Criteria } \\
\hline$\geq 85 \%$ & Very positive \\
\hline $70 \%-84 \%$ & Positive \\
\hline $55 \%-69 \%$ & Moderate \\
\hline $40 \%-54 \%$ & Negative \\
\hline$\leq 39 \%$ & Very negative \\
\hline
\end{tabular}

The reliability coefficients were computed in Cronbach's Alpha and come the results are as follows: teachers' knowledge in ICT online learning $(\alpha=.91)$ and teaches' perception in ICT online learning $(\alpha=.80)$. Furthermore, a group interview had been executed by asking questions directly to identify their experience and perceptions, and preferences of ICT integration. 6 teachers were selected and took less than thirty minutes to finish the session, then also was recorded written. Briefly, their responses will be described descriptively.

\section{$4 \quad$ Findings}

\subsection{Teachers' knowledge of ICT integration}

From the results of the data (Table 3), it shows that the knowledge toward the use of gadgets/smartphones is slightly higher $(\mathrm{M}=4.5)$ than the knowledge toward the use of computer/laptop $(\mathrm{M}=4.4)$.

Table 3. Mean score of knowledge of current technology

\begin{tabular}{|ll|c|l|}
\hline Knowledge of the Current Technology & Mean & \multicolumn{1}{|c|}{ Interpretation } \\
\hline $1 . \quad$ Gadget/smartphone & 4.5 & High \\
\hline $2 . \quad$ Computer/laptop & 4.4 & High \\
\hline \multicolumn{2}{|c|}{ Average } & 4.4 & High \\
\hline
\end{tabular}

Even though the gap score in between is little, but, this is indicated that teachers are more familiar to use smartphone as it is friendly to use and been part of their daily life, for the communication tool with co-workers or with learners, for emailing or announcing tasks to the learners through Whatsapp/FaceBook group, doing small tasks such as 
reading or scanning learners' submitted tasks, and even searching or receiving information with it. Noted this, as they have spent much time using smartphones/gadgets, they surely have attained much understanding to operate this device. Computer/laptop, on the other hand, it must be used for larger work, such as creating a bunch of documents about learners' report, encoding learners' data or grade, and editing a bunch of files whether about schools' or learners'. Nonetheless, both of these mean score represented that teachers' knowledge toward these devices, in total, is high $(\mathrm{M}=4.4)$ means they have no difficulties operating it.

Next, the result of the data on the table (Table 4) interprets that the knowledge of using Microsoft Word is higher $(\mathrm{M}=4.4)$ compared to the ability to operate Microsoft PowerPoint $(\mathrm{M}=4.1)$.

Table 4. Mean score of knowledge of the platform/LMS

\begin{tabular}{|ll|c|l|}
\hline \multicolumn{2}{|c|}{ Knowledge of Platform/LMS } & Mean & \multicolumn{1}{|c|}{ Interpretation } \\
\hline 3. & Microsoft Word & 4.4 & High \\
\hline $4 . \quad$ Microsoft PowerPoint & 4.1 & High \\
\hline \multicolumn{2}{|c|}{ Average } & 4.3 & High \\
\hline
\end{tabular}

The possible reason that may represents from this findings is that, why Ms. Word score is high, teachers are more familiar with the use of Microsoft Word and much time spent on it because many tasks can be done through this platforms, for instance computing data, inputting numerical data along with the formulas, typing letter, typing tasks and tests for learners in a big number and so on. As most of the tasks primarily spent on this platform, clearly, they learning management system for this platform is surely reliable. Different with Microsoft PowerPoint, however, a bit lower than Word due to less frequently used since only used for presentation and during the class time whether virtually or offline because it is very useful for teachers in delivering the lesson material for learners. Regardless, teachers' knowledge in managing learning system is high $(\mathrm{M}=4.3)$ indicating they have qualified capability toward it.

Next, the score on the table (Table 5), based on the Likert-scale, resolves that their ability to utilize online learning content and ability to utilize YouTube content for learning were moderately higher $(\mathrm{M}=3.7, \mathrm{M}=3.7)$.

Table 5. Mean score of knowledge toward online tools

\begin{tabular}{|ll|c|l|}
\hline \multicolumn{2}{|c|}{ Knowledge of Online Tools } & Mean & \multicolumn{1}{|c|}{ Interpretation } \\
\hline 5. & Utilizing YouTube content & 3.7 & Moderately high \\
\hline 6. & Virtual meeting through Google Meet or Zoom, etc. & 3.5 & Slightly above average \\
\hline 7. & Utilizing online learning content & 3.7 & Moderately high \\
\hline \multicolumn{2}{|c|}{ Average } & 3.7 & Moderately high \\
\hline
\end{tabular}

Compare to the previous table (Tables $3 \& 4$ ), the attained result is bit lower though it only degrade one level. This can be seen that teachers' knowledge in managing the online content learning in English teaching practices is well enough, that also leads that there are still much room to enrich their understanding in managing the online content, 
such as implicating the strategy for particular content, much more for choosing and applying the suitable content for learners' level. Utilizing a virtual meeting, on the other hand, is scored slightly above average $(\mathrm{M}=3.5)$ which resolves that their understanding to operate or to hold a virtual meeting is well enough. This must be due to the sudden change of learning methodology where mostly were conducted traditionally before the pandemic. Hence, the teachers seem still trying to get along with this sudden change. However, with the attained score $(\mathrm{M}=3.7)$ also means that the teachers are capable in handling the sudden changes and current teaching-learning situation.

Then, the current table (Table 6) represents teachers' knowledge toward the ICT content in English learning material, based on the Likert-scale the result come as follow:

Table 6. Teachers' ICT-content knowledge

\begin{tabular}{|ll|c|l|}
\hline & ICT-Content Knowledge & Mean & \multicolumn{1}{|c|}{ Interpretation } \\
\hline 8. & Using ICT to perform the English learning material & 4.0 & Moderately high \\
\hline 9. & Using ICT to communicate the English learning material & 4.4 & High \\
\hline 10. & Using ICT to make English learning process enjoyable & 4.2 & High \\
\hline Average & 4.2 & High \\
\hline
\end{tabular}

It appears that the knowledge of teachers in the use of ICT for communication is high $(M=4.4)$ which means the teachers are already accustomed using the social media software or using email to forward the tasks and the learning material to their students which resulted excel in managing the ICT for communication. In addition, their knowledge of ICT in creating the English learning atmosphere enjoyable is high $(\mathrm{M}=4.2)$. Which proves that they are qualified in managing ICT in the teaching-learning process so they can develop and collaborate the learning content that are useful and interesting for students which beneficial for them. It is also showed that their knowledge of the use of ICT in displaying or projecting images, sound, and video is moderately high $(\mathrm{M}=4.0)$ which means good, either; however, it is also mean that their skills can still be honed further in order to achieve further better results in the ICT-content knowledge. Nonetheless, teachers' understanding in this terms is high indicating they are competent using ICT content knowledge $(\mathrm{M}=4.2)$.

Besides that, from the obtained data in the table (Table 7), it is showed that the use of ICT for the direct learning method $(\mathrm{M}=4.2)$, the project-based learning method $(\mathrm{M}=4.1)$ and the discovery-based learning method $(\mathrm{M}=4.1)$ are higher than the use of ICT for collaborative-based learning method $(\mathrm{M}=3.6)$.

Table 7. Teachers' ICT-pedagogical knowledge

\begin{tabular}{|ll|c|l|}
\hline \multicolumn{2}{|c|}{ ICT-Pedagogical Knowledge } & Mean & \multicolumn{1}{|c|}{ Interpretation } \\
\hline 11. & Using ICT for direct instruction & 4.2 & High \\
\hline 12. & Using ICT for project-based teaching and learning & 4.1 & High \\
\hline 13. & Using ICT for discovery-based teaching and learning & 4.1 & High \\
\hline 14. & Using ICT for collaborative-based teaching and learning & 3.6 & Moderately high \\
\hline & Average & 4.0 & High \\
\hline
\end{tabular}


This indicates that the teachers still inflexible to combine ICT with the collaborativebased learning model. The reason is since it takes a good understanding from the teachers toward the meaning of this learning-based model and much further, on the other hand, a great supervision from the teachers are required to guarantee its effectiveness during the English teaching and learning practices. In addition, there is also a tendency to rely only to one person among the learners which is not very beneficial in such situation. These is should be the common reasons of why the obtained score was somewhat lower than the other three. Despite everything, as the data shown above, the result is moderately high $(\mathrm{M}=4.0)$ which means knowledgeable in managing the ICT as the pedagogical knowledge.

Meanwhile, the results showed that on the table (Table 8) resolves that, knowledge of the use of ICT to enhance the English content material $(\mathrm{M}=4.1)$ and knowledge in combining ICT with authentic material in the English language learning $(\mathrm{M}=4.3)$ is higher compared to the use of ICT in the efforts to cultivate learning autonomy among the learners $(\mathrm{M}=3.6)$ and the application of a variety of strategies and approaches to support learners' understanding in learning English $(M=4.0)$ supposed that only at moderate level.

Table 8. Teachers' ICT-pedagogical content knowledge

\begin{tabular}{|c|c|c|c|}
\hline \multicolumn{2}{|r|}{ ICT-Pedagogical Content Knowledge } & Mean & Interpretation \\
\hline 15. & Using ICT to enhance the English content material & 4.1 & High \\
\hline 16. & $\begin{array}{l}\text { Combining ICT with authentic material in English } \\
\text { teaching }\end{array}$ & 4.3 & High \\
\hline 17. & Using ICT to foster learners' English learning autonomy & 3.6 & Moderately high \\
\hline 18. & $\begin{array}{l}\text { Applying different strategies and approaches with } \\
\text { English content to support learners' understanding }\end{array}$ & 4.0 & Moderately high \\
\hline & Average & 4.0 & High \\
\hline
\end{tabular}

The results of this diversity points that teachers still do not have much knowledge yet, and on how to, or what strategy or approaches could be applied which resulted slightly lower in score. But in spite of that, their ICT as the pedagogical content knowledge is high which means they competent in this term $(\mathrm{M}=4.0)$.

Finally, as the data have been analyzed, teachers seemed have no difficulties operating the current technology. That has been indicated from how well they could operate, the digital devices, the learning management system and platform along with to utilize the learning online content; plus with the plenty room for enrichment, the teachers would have attained much achievement in terms of ICT knowledge.

\subsection{Teachers' perception toward the ICT integration}

As the data been collected by using the Likert-scale and using the percentages score to determine their perception level that refer on Table 2. The interpretation is arranged from the highest to the lowest, the result comes as follows (Figure 1): 


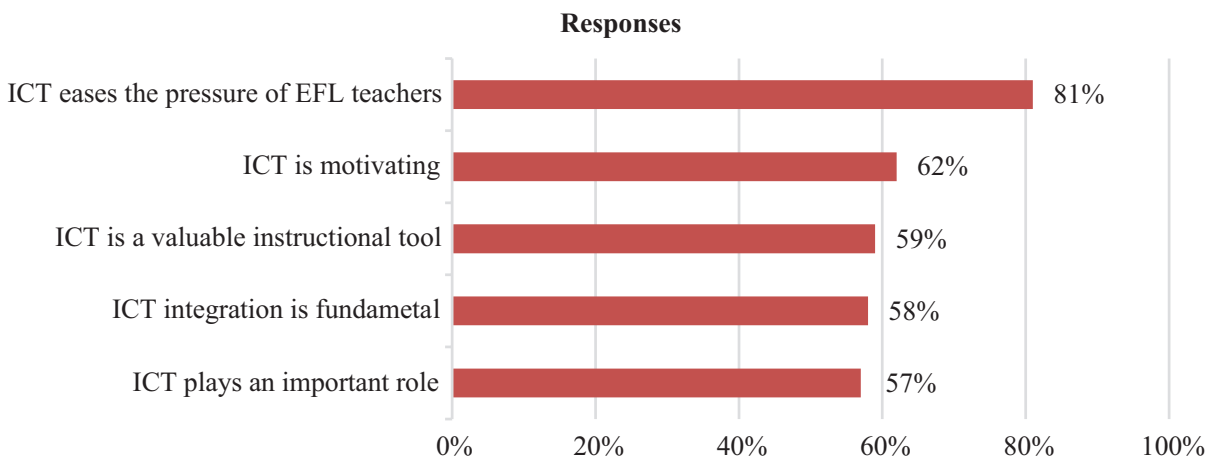

Fig. 1. Percentage score of respondents' perceptions of ICT

The statement which stated as the use of ICT eases the pressure on me as the EFL teacher in this new normal setting (item \#19) proves the teachers were gaining positive perceptions of toward this notions $(81 \%)$. This is indicated that almost all teachers were having positive perception toward the usefulness of ICT in decreasing their load as the teachers in this current pandemic in enriching their learners globally.

While the statement which stated as ICT integration motivates learners to get more involved in the EFL teaching-learning practices in this new normal setting (item \#22) indicates participants were moderately agreed $(62 \%)$. The finding showed that not all the teachers agreed if by integrating ICT into the English learning practices could make them be motivated. The reason must be that the technology itself could also hindering them be more engaged in learning since it has many distractions that possibly could lead learners not focus to the learning processes, as well.

In terms of the affirmation stating ICT is a valuable instructional tool in ELT class (item \#21) moderately agreed toward by them (59\%). Again, the respondents were showing not very fancy toward this notion. This represents that ICT is not vitally a valuable instructional tool ELT classes since, they may be thought, ICT itself should not be vital in ELT but if accompanied with a proper strategy or approach in learning, an authentic used content and the proper classroom management then only the teaching-learning practices will proceeds effectively.

Further, the word which stated as ICT integration is a fundamental component in ELT practices in this new normal (item \#23) were moderately perceived by the participants (58\%). Participants agreed that ICT is not fundamental of ELT practices in this new normal setting this must be due to not all schools, teachers and learners are equipped with the advanced technology such as laptop or gadget which resulted in difficulties to apply the ICT-based leaning style. For more causes will be discussed in discussion session.

Last but not least, the argument which represented as ICT plays an important role in ELT practices in this new normal (item \#20) were moderately agreed by the respondents $(57 \%)$. This also strengthens the previous thoughts toward the ICT itself that is not all schools, teachers and learners are ready and competent in learning English through ICT. It has to do with the hindrances stated earlier argued in paragraph above. 
Briefly, all the teachers' responses seemed demonstrated that ICT role in this new normal is situational, where there is a time it is vital and while there is also a time it is not vital, it depends on the schools' situation on how ready they are in managing this sudden change. After everything, it is still useful in this current situation, however.

\subsection{Findings on Teachers' thoughts about ICT integration in new normal}

After quantitative data were successfully collected, the open-ended interview was carried out in order to see deeper about their thoughts toward integrating ICT in ELT practices in this new normal; the results come out are as follows:

\section{The importance of ICT integration}

- Teacher\#2 (Nov 2 $2^{\text {nd }}, 13.01$ p.m.): It has a big role in this new normal since helps us to conduct remote learning.

- Teacher\#3 (Nov 2 $2^{\text {nd }}, 13.03$ p.m.): The role is good because the ICT tool helps me in conducting the teaching-learning process for learners [with online applications].

- Teacher\#5 (Nov 2 ${ }^{\text {nd }}, 13.03$ p.m.): It would helping me since it is handy in organizing the material to be attractive and fun to learn.

- Teacher\#6 (Nov $2^{\text {nd }}, 13.04$ p.m.): The role is nice [because of its benefits in reaching students for communication].

The importance of ICT in new normal era could be seen from the 4 teachers' statement above. The role is good or it has a big role was stated by the all 5 interviewees. This findings should strengthen their thoughts in Figure 1 where 81 per cent of the participants agreed that ICT could lighten their burden in ELT practices the midst of the COVID-19 in terms of conducting learning process virtually and for communication.

In contrast to all 4 teachers' commenters earlier, however, the comments of 2 teachers among them was bit different:

- Teacher\#1 (Nov 2nd 13.01 p.m.) : It helps me in the English teaching-learning process to visualize images, videos, animation, etc. But it will not always as important as it is seen because it is difficult to teach them with the face only displayed on the screen.

- Teacher\#4 (Nov 2 ${ }^{\text {nd }}, 13.04$ p.m.): It has a good role, but transferring the knowledge to students [only through the screen] effectively is difficult to conduct.

It is shown that the teachers perceived the role is good, however, to create the teaching-learning practices effectively is encountering difficulties since the practices only displayed on the screen. It means that, there is no direct experience can be provided to support learners' full understanding toward particular topic. Teachers can still do ELT practices but to make them fully understand it is difficult, it has to do with the learners' level that still in junior high school which means explaining verbally to them is inadequate, and the different learning styles also learning needs among them would require more than just learn virtually.

Teachers' ICT proficiency. In this session, there were three proficiencies were introduced; firstly, Low proficiency, means that lack of authentic knowledge in operating ICT in ELT practices; secondly, intermediate, means that the knowledge to 
operate simple or basic stuff in ICT for teaching is adequate; thirdly, high, means that the participants have no difficulties and excel in operating, integrating and managing the ICT in ELT practices. Eventually, there was no instrument to test out their proficiency, however, the interviewees were solely asked how they would perceive their own capacity in terms of this proficiency. The results are as follows:

4 out of 6 teachers perceived that they have an intermediate ability in operating the ICT in ELT practices:

- Teacher\#1 (Nov 2nd 13.06 p.m.): I can say my proficiency is just at normal/ intermediate.

- Teacher\#2 (Nov 2 ${ }^{\text {nd }}, 13.06$ p.m.): Overall, I would agree to regard my-self at normal/ intermediate stage.

- Teacher\#3 (Nov $2^{\text {nd }}, 13.06$ p.m.): The same, intermediate user is suitable for me.

- Teacher\#6 (Nov 2nd 13.06 p.m.): I feel the same way, I am at intermediate.

This data revealed that they are confident to operate the gadget or laptop along with the basic software or hardware or even to run the application with ease as shown in the Tables 3 and 4. In contrast to 4 commenters earlier, however, the 2 teachers are believed to have low proficiency.

- Teacher\#4 (Nov 2 ${ }^{\text {nd }}, 13.06$ p.m.): I can say my proficiency is low because I am not familiar with the current technology stuff.

- Teacher\#5 (Nov 2 $2^{\text {nd }}, 13.07$ p.m.): I am at low because not have many experiences of doing that and often forget what should I do next if am at the front of the laptop/ computer or gadget/smartphone.

2 teachers are perceived themselves as the low expertise users of ICT, the reasons is that they are not familiar and not have many experiences before to operate ICT tool. Clearly, these two teachers' needs in ICT literacy still lacking which is not good for their professionalism growth, the concerns from institutions is required to make sure they are well equipped and prepared to face advancement of digital era. The possible factors that would manifest them are that psychological factors, such as, motivation, ICT-self-efficacy and even age or cultural or financial background. They are not the main concern in this study but the study merely aware those potential factors would affect to their proficiency.

They enjoyment of working with ICT integration. The interviewees had been asked how please they integrate ICT in ELT practices, 3 out of 6 teachers believed that it is pleasing to work accompanied by ICT:

- Teacher\#1 (Nov 2nd 13.08 p.m.): It is pleasing because I can elaborate the content material with pictures, audio or even with videos.

- Teacher\#2 (Nov 2nd 13.08 p.m.): Yes, I enjoy, besides, it could help to deliver the material easily through social media group (WhatsApp \& FaceBook), it could help me to gather the information [content material] for learning with no doubt.

- Teacher\#6 (Nov 2nd 13.08 p.m.): it is enjoying because it is helpful to collect information and to find information. 
The 3 teachers seemed agree they are having a good time using the advantages of ICT to deliver the material with ease, combining material with different pictures or audios or videos to make learning practices attractive. Hence, they agreed that integrating ICT is conveniently enjoying.

On the other hand, the other 3 teachers seemed view it situational.

- Teacher\#3 (Nov 2 $2^{\text {nd }}, 13.08$ p.m.): if the tools run well, the required tools are all available and if the number of computer at the labs are adequate then the teachers and their learners should enjoy using it.

- Teacher\#4 (Nov 2nd 13.09 p.m.): it is not enjoying if we are not well prepared for it.

- Teacher\#5 (Nov 2nd 13.09 p.m.): it is not enjoying if there is new application like nowadays like Zoom or somewhat [called it] Google meeting which need much steps need to be done.

It can be stated that it is stressing them if they are unfamiliar with some new software such as Zoom, Bluejeans, Voxtrot, Skype, and likewise software which needs much steps to do. In other words, the longer the steps they are required to fill in the stresses they be which resulted pressuring them not enjoying them. It should be time consuming for them to prepare it when they must do immediate teaching.

\section{The challenges and barriers}

Learners' lack of ICT infrastructure and literacy. The results further showed that the low/lack of internet network, inadequate laptop or personal computer among the learners, and low literacy to operate computer software or smartphone applications were the common challenges in ICT integration (teachers\#1, 2, 3, 4, 5, 6).

- Teacher\#1 (Nov 2 $2^{\text {nd }}, 13.09$ p.m.): the facility is inadequate among all the learners because not all of them would able to purchase it. Besides that, the illiterate among the learners to operate particular software or application is also be the obstacle because ITC is no longer a subject in our [junior high school] curriculum. It has been replaced by the local content (MuLok). The reason is that the ITC could be learned independently by the learners.

- Teacher\#2 (Nov $2^{\text {nd }}, 13.14$ p.m.): it is stressing to apply ICT based learning when the network connection is low or bad, which hindering the learning process.

- Teacher\#3 (Nov 2 $2^{\text {nd }}, 13.15$ p.m.): the bad connection is really annoying when have to do E-learning. The digital devices seemed useless without it.

- Teacher\#4 (Nov 2 $2^{\text {nd }}, 13.16$ p.m.): our schools still limited to wi-fi connection, so there is no way our school could reach our students through online.

- Teacher\#5 (Nov 2 ${ }^{\text {nd }}, 13.16$ p.m.): learners need direct explanation or supervision. If only directed through screen they are having difficulties to understand.

- Teacher\#6 (Nov 2 $2^{\text {nd }}, 13.17$ p.m.): not all parent are not able to purchase the digital devices.

It is found that, the financial problem could be the issues which hindering the learners to have access to ICT. It is also showed that no or bad/low internet connection, seems be the issues in ICT integration. In other words, the effectiveness of ICT integration depends on the internet access and the complete equipment which the school 
have. School's condition seems be the factor to the ICT effectiveness. Much further, the interesting fact that the ITC subject in the curriculum has been replaced with the local content subject. Unfortunately, such action would adverse the needs of the learners' most required skills in 4.0 era where all the ICT integration is going to be universally applied. If schools thoughts that learners could learn it autonomously, some are able and some are not able to do that, learners clearly will end up only using it for gaming and for entertainment sake. ICT literacy is needed to be taught in schools.

Learners' motivation. While integrating ICT in ELT practices has been discussed, teachers had been asked how well do they perceive their learners' motivation in learning English with ICT integration in new normal; the results come as follows:

- Teacher\#1 (Nov 2 $2^{\text {nd }}, 13.21$ p.m.): students were motivated at the beginning but as time goes on they become less motivated.

- Teacher\#2 (Nov $2^{\text {nd }}, 13.21$ p.m.): they were less motivated because the learning environment is not the same as they were [before COVID-19] in classroom situations.

- Teacher\#3 (Nov 2 ${ }^{\text {nd }}, 13.21$ p.m.): they were less enthusiastic with just facing the screen.

- Teacher\#4 (Nov 2nd 13.22 p.m.): some of them are excited to use their smartphone. Some are not, the causes are easy to get distracted and unfocused and not comprehend the material very well which leads to laziness.

- Teacher\#5 (Nov $2^{\text {nd }}, 13.22$ p.m.): easily to get distracted by social media and gaming applications.

- Teacher\#6 (Nov 2 ${ }^{\text {nd }}, 13.22$ p.m.): no, because they having difficulties understanding the material without further explanation, especially, with gestures or mimic or touches [direct explanation or face to face experience].

Based on the comments. most learners were not motivated by only learning with digital devices. The first reason is that they get bored. Perhaps, in the beginning they are all very enthusiastic toward the idea because they can learn from home with only through smartphone as the media, however, as the time goes, many of whom perceived that it was not very interesting anymore. It leads to the second reason that there is no actual experience; a sense of learning in the classroom; interacting with peers and teachers as well as environment. Because there is no real experience due to only facing the screen during the class hour. They become lazy to participate much further. This confirms that face-to-face learning method is more engaging for some learners while for others E-learning may be more engaging. It is a atter of fondness and familiarity as well as method. The other reason is that they are easy to get distracted. Most current digital devices have been completely equipped with many features, for example, entertainment stuff and social media means that using them for learning possibly could distract their attention in the span on the learning process. They are tempted to involve in social media and entertainment.

The strategies and approaches to overcome the barriers. After the barriers and the challenges of ICT integration in new normal have been exposed, interviewees were asked what they will do to overcome those barriers.

Home visit learning. They revealed that (teachers\#1, 2, 3, 4, 5, 6) returning to the traditional learning method where basic English books as the prime source of learning would be the main solutions. 
- Teacher\#1 (Nov 2 $2^{\text {nd }}, 13.18$ p.m.): we can only teach students with basic English books only as of the media.

- Teacher $\# 2$ (Nov $2^{\text {nd }}, 13.19$ p.m.): the media such as whiteboards, books, and pictures should be the best stuff if there is no access to the internet.

- Teacher\#3 (Nov 2 $2^{\text {nd }}, 13.19$ p.m.): the students should be approached manually by returning to the traditional method with books, paper will be the source of learning.

- Teacher\#4 (Nov $2^{\text {nd }}, 13.19$ p.m.): applying small group learning should help them whether visiting them or invite them to schools.

- Teacher\#5 (Nov $2^{\text {nd }}, 13.20$ p.m.): applying the traditional learning method.

- Teacher\#6 (Nov 2 $2^{\text {nd }}, 13.20$ p.m.): teaching them directly [face-to-face] teaching with gestures, visualization, and actual experiment should be enough [to transfer the knowledge to the students].

All of the interviewees seem to agree that learners with no computer/laptop or smartphone should be reached manually by home visiting or Luring (Luar Jaringan). In this practice, teachers are guided to visit their learners at their home, fully equipped with the learning material that has been prepared by the institutions as the content for them. Hence, the printed books, pencil and papers will be the main media in learning. Besides visiting their houses one by one, inviting the learners come to schools also will be the way out whereas the printed books provided by the schools will be the main media in learning. However, the number of learners is limited. It is planned for only 8-12 learners per group for merely 30 minutes to 40 minutes to study at.

Soft skill building. In terms of fostering the soft skill, the teachers have been asked what soft skill that they emphasized during the ICT integration in this current situation. The answers are as follows:

- Teacher\#1 (Nov $2^{\text {nd }}, 13.23$ p.m.): honesty and respect

- Teacher\#2 (Nov $2^{\text {nd }}, 13.23$ p.m.): discipline and responsibility

- Teacher\#3 (Nov $2^{\text {nd }}, 13.23$ p.m.): politeness and respect

- Teacher\#4 (Nov $2^{\text {nd }}, 13.24$ p.m.): politeness and active in the class time

- Teacher\#5 (Nov 2 $2^{\text {nd }}, 13.24$ p.m.): honesty

- Teacher\#6 (Nov $2^{\text {nd }}, 13.25$ p.m.): active in communicating not just silent

Based on the findings. it appears that some soft skills were needed to be highlighted since the online learning could only be done from ones' home. It is a sort of efforts to manage the online class and encourage the establishing of character education; soft skills in learning interaction. The sense of honesty and responsibility in working on assignments or even examinations test is required. In addition to, the sense of respect and discipline are also demanded in learners' consistency and obedience to time frame of the class, not to mention the vitality of the politeness and activity in virtual or online class. The conduciveness and success of class participation and interaction as well as achievement are determined by such traits.

The contribution of ICT integration to the EFL meaningful learning. Further, the interviewees were asked to describe how they will define the English meaningful learning with ICT integration. Not just that, they were asked how they will make it into realization; the responses are as follows: 
- Teacher\#1 (Nov 2nd, 13.25 p.m.): students were able to understand the content material given during the class hour, there was back and forth feedback between students and teacher.

- To make it come true is by giving them direction on how will the learning process will occurred, and how they should behave when been given tasks to do.

It appears that the leaners' understanding constitutes one of the components in a meaningful learning. For that, teachers viewed that feedbacks are vital in leaning. It has to exist in interaction among teachers with learners and peers-to-peers. That has to be accompanied by the act of giving a direct instruction which seemed to enhance the meaningful learning. It would guide them to be aware of and focus on the current topic or situation and, later, be directed how they supposed to respond.

- Teacher\#2 (Nov $2^{\text {nd }}, 13.26$ p.m.): students were active whether in listening or asking, students were appreciating each other, and students know that they are studying and what to do after it.

- To make it successful, setting up some rules and preparing the [authentic] material.

The meaningful learning also means that they know how to appreciate teachers and peers. In so doing, a conducive learning atmosphere takes places. The learners enjoy the learning process without feeling of isolation. This may even stimulate the sense of longing for interacting with teachers and classmates. It does not only overcome the hindrance of distance and boredom for traditional learning but also to provide the time to engage with friends; a sort of social gathering. Surely, it is carried out by prescribing certain rules to manage and administer the class in order to guarantee the attainment of the learning goals and fruitful interaction. One of the teachers added,

- Teacher\#3 (Nov $2^{\text {nd }}, 13.26$ p.m.): having a sense of responsibility.

- To make it realized, setting rules and rewards and consequences. Discipline must be the priority.

These comments seem to underline the importance of establishing the sense of responsibility to advocate the meaningful learning. Setting up rules is not intended to limit the learning interaction or activities yet it is a part of designing learners to consider materials and assignments as something that have to be done in terms of learning. It is pivotal to ensure the online activities run as planned. It is pointed out by one of the teacher respondents in the following expressions,

- Teacher\#4 (Nov 2 ${ }^{\text {nd }}, 13.27$ p.m.): students were active in participating in group discussions.

- To make it done, setting boundaries so students will not go wild and giving the authentic material.

The respondent emphasized that rules contribute to the making of the active interaction in the learning process. This active learning process indicates that the meaningful learning is already taking place as acknowledged by teacher\#4. It is justified by the response of the teacher as bellow; 
- Teacher\#5 (Nov 2nd 13.27 p.m.): students can practice what had been taught. To do that, teachers can inspire and direct them to do their best in their learning process.

This response clarified that the active learning implies that, in the eyes of the teacher, learners know what to practice what has been taught. It is not only about memorizing the given materials but also, more than that, enacting critical and creative thinking. Learners see teachers with the materials as the source of inspiration to elaborate and dig out more knowledge and practices. The other teacher added,

- Teacher\#6 (Nov 2 $2^{\text {nd }}, 13.28$ p.m.): the given material is being understood by the students so they will know what to do or to learn next.

- For making a success, by preparing the content and make it as attractive as possible to the learning; by also giving feedback.

The teacher seemingly explicated that the active learning in the frame of a meaningful learning is not apart from preparing the authentic learning content and design. It is together with the aspect of giving feedback and building a good communication. These aspects have to color the activities of the class.

In brief, these interviewees' answers illustrated that the role of ICT is much-helping, especially in this current pandemic era. It assists the making of the meaningful learning. Some boundaries are tackled by the application of ICT. However, it has to also to be acknowledged that few hindrances remain challenging to solve. For example, enhancing teachers' competence in the use of ICT through and providing supporting online networks and infrastructure in every school is something to be considered for ensuring the attainment of the meaningful learning.

\section{Discussion}

From the findings, the knowledge of teachers on the application of technology in online learning indicates an obvious result (Table 3). First, there is a sub-section of knowledge towards current technology, it was found that their knowledge of operating gadgets/smartphones is higher than on the use of the computer. It is influenced by comfort in using a smartphone because of the ease in accessing, communicating, and if it is occupied with some helper app like social media, news, and so on will greatly help in processing the content material and are useful in the process of teaching and learning foreign languages [32]. Whereas with the use of a computer/laptop in learning, which may be used as optional if the smartphone is not in use. For example, for a larger tasks such producing, designing, structuring tasks for infants, calculating a large data for learners' report in the end of the semester, producing letters and so on, surely, the smartphone would not support this as much as the computer, the smartphone could be used, but through computer will be much more efficient because it built for that tasks [33]. However, without disregarding the valuable value computer has, but, if the computer and the smartphone are applied simultaneously in ELT practices then the process of teaching and learning, communication between students and teachers will be more smoothly [34], [35]. With the score results obtained, it could be stated that the teachers' knowledge of the latest technology of the English language teacher in junior 
high school level in Bitung city is high. In other words, they are capable of executing and activating and make use of the current technological equipment for EFL online class and displayed willingness to change or adapt with current situation. The previous study exposed the different outcomes [36]. Observing respondents' age, the outcomes displayed, not all the teachers perceived the usefulness and be willing to adapt with the ICT integration. It appears that the apprentice teachers are more willing to adapt with ICT integration because the eagerness to explore the features and to attain new experience that they have. The mature teacher, contrariwise, prefer to learn without ICT integration because it is time consuming. This finding should provide the new insight concerning with how the age could affect respondents' willingness to integrate technology.

The second, in sub-section knowledge on the management of the application, it was found that the use of Ms. Word is higher than in the use of Ms. PowerPoint (Table 4). It is reassuring that teachers today are very familiar with the use of Ms. Word, where almost the rest of the work in data processing, such as displaying images, audio, charts, and tables can be done with this software, including the process of teaching and learning. Ms. PowerPoint, on the other hand, with all the ease that had been offered for the teaching and learning process, had scored a little lower. Features provided by Ms. Power Point are already adequate, especially in terms of conveying the material in a simpler form without having to include all the words accompanied with the pictures and videos will be able to make the process of delivering the material so much more interesting and not monotonous. However, the reason that may still be the obstacle is the teachers are still not too well using the software such as Ms. Power point due to the slightly different features with Ms. Word which makes them confused if not being taught, especially for those who have low experience which described at their comments by teachers\#4, 5 in the session of ICT proficiency. It is discouraging for them to adapt with new features while they do not familiar to operate because they may be proficient engaged at the same applications, in this case, Ms. Word, but not for others that they occasionally engaged with [37]. Nonetheless, the teacher's knowledge of the English language at the junior high school level in Bitung city is fairly high, with that being means respondents should be able, with some practices, to manage and make use of it for ICT learning online.

In addition, their knowledge in managing online learning and content in ICT integration is revealed. It was found that the management content of YouTube and other online learning have scored moderately high (Table 5). This shows that their knowledge is still lacking. Online content offers abundant source which will greatly facilitate teachers in the development of the content material in the learning process. Studies prove that the use of online material in learning allows the teacher to establish new knowledge and insight rather than just doing traditional learning, and also allow students to grow in knowledge and achievement of language learning [38], [39]. The possible problems are that the lack of knowledge in integrating online content, what content is suitable, fails to comprehend which specific sites to be used, and in managing the content (Teacher\#1' comment in challenges and barriers session). In addition to the factor of low technological literacy (Teachers\#4 \& 5 in the session of ICT proficiency), factors such as age, experience, motivation, self-confidence, need to be supervised by the institution of the school to give close attention and empowerment to the teachers and if been 
completed with the cooperation and mutual help between co-workers, can surely promote the quality of teaching with technological integration. The success or failure of the technological integration in teaching depending on the effectiveness of the school and the government in empowering educators with authenticable knowledge [40]. It also applies the same to the use of the application such as Google Meet or Zoom or the like of these which have a quite lower the attention. A sudden change due to pandemic made all school elements struggling to adjust and to transform to the distance learning that was only accustomed to the traditional learning method [41], [42]. Additionally, some studies also expressed that this pandemic have manifested the changing transformation from face-to-face learning method to the technological learning method [43], [44]. Hence all of teachers, staff and institutions are pushed to do remote learning in the unlimited times.

This imposes educational institutions in Indonesia including in the area of Bitung city to start administering technological integration in the learning process. It is challenging since currently the subject of ICT at the junior high school level has been removed and replaced with local content. That means that a breakthrough is required and recommended to meet this circumstance. The ICT literacy needs to be endorsed and encouraged again. It is relevant with the teachers' perception toward the implementation of ICT in the present learning tendencies.

In the part of the perception toward ICT, the results imply that ICT can ease the teachers' pressure received positive attention in the middle of this pandemic (Figure 1). It is believed that ICT can reach out to students at home as well as facilitate teachers in delivering teaching materials to the students. Furthermore, it is quite agreed that the application of ICT can foster students' motivation in learning. It disconfirms the researchers' hypothesis which the result should be high considering all of the advantages offered by the ICT integration and also shown by previous studies [45]-[47] whom reporting that learners were really motivated to learn more when it is integrated with technology, what is more, their achievement seems higher than just using the traditional one [48]. Yet, the findings of this study contradictorily pointed out that the ICT application in this new normal could not successfully foster learners' motivation in learning due to lack of authentic experience as it was in the classroom where they can interact directly with teachers and experience feedbacks during the learning process. They are also difficult to focus and to comprehend the given material in terms of virtual learning. Further, it has to admitted the influence of other factors such as availability of facilities, the number of students in the classroom, students' awareness, family cultural and financial background, and as well as the ability and self-efficacy toward the technology itself [49]. Thus, teachers continually pay attention to students' needs in language learning by providing interesting content, the variation between individual work and group work, and providing technological literacy will greatly help them in the learning process. These results seem to reinforce some other studies which proved that actually blended learning can improve the performance far better than traditional learning [50]. Teachers ought to utilize technology in learning in terms of attempting to improve students' achievement in English language learning in any setting.

Further, the result in the Figure 1 asserting that ICT is valuable tool in learning English is moderately agreed by the participants. Fewer than half of the respondents were convinced that ICT is not always important in the learning process especially in 
the situation of the pandemic nowadays. It is subject to the school condition and technological infrastructure as well as student-teacher readiness. Some schools might have the technological facilities but some other particularly in the edge of the city might not be that fortunate. It is also related to educational budget distribution which was not equally allotted in the past days or the financial capacity particularly those of private schools. Thus, it is not all of the schools possess adequate computer laboratory or other ICT components (Teachers\#4 in ICT barriers interview session). Besides, the sudden emergence of the pandemic, the students are not all being mediated by advanced learning tools such as laptop or computer and also a smartphone. It is complicated by the instability or even absence of internet connection, financial obstacle, and cultural perception of the learning process. (Teachers\#6 in ICT barriers interview session). The research finding tends to strengthen the reasons why educators EFL teachers of junior high school in the city still compelled to apply traditional learning due to such concerned conditions. This is in line with some studies revealing that many regions in Indonesia remain unable to fully implement the ICT integration in the learning process its usefulness and motivating aspects. These may root in the lack of facility and literacy to operate which lead to the different learning experience between schools in urban and rural area [51], [52].

\section{Conclusion}

The results of the study suggested that that teachers' knowledge and perception toward the integration of ICT in the learning process during the pandemic is positively high. Yet, it may have some obstacles to apply concerning with the familiarity and readiness of the relevant learning components. The result of this study, to some extent, revealed that not all schools are prepared with adequate technological facilities in conducting online learning. In addition, teachers are also in the need of more updates of knowledge related to the application and integration of ICT for more effective learning process. The discussion on the analysis also suggests that the internet connection and its financial consequences can be the other hindrance to tackle. For these circumstances, therefore, some efforts such as providing necessary ICT components in schools, preparing teachers for more digital literacy, and saving more time for learners' feedbacks and interaction are worth to implement. As research, since this study merely involves teachers who belong to the English Teacher Regional Forum (MGMP Bahasa Inggris), more studies on larger teacher participants with different ICT variables might be advised for more breakthroughs for current learning process.

\section{$7 \quad$ Acknowledgement}

Authors would like to extend their gratitude to Research and Community Outreach Institution Unima, Indonesia, for facilitating and supporting this research, and for Connecting Asia Malaysia for the partnership in consultancy and facilitation, for iJim for publishing this research article through strict and constructive selection and review. 
[1] Abdelraheem, A. Y., \& Ahmed, A. M. (2015). Effects of Activity Based Blended Learning Strategy on Prospective of Teachers' Achievement and Motivation. Journal on School Educational Technology, 11(1), 10-19. https://eric.ed.gov/?q=achievement+and+blended+learning\&ft=on\&id=EJ1097417. https://doi.org/10.26634/jsch.11.1.3550

[2] Ahmadi, D. M. R. (2018). The Use of Technology in English Language Learning: A Literature Review. International Journal of Research in English Education, 3(2), 115-125. https:// doi.org/10.29252/ijree.3.2.115

[3] Ali, W. (2020). Online and Remote Learning in Higher Education Institutes: A Necessity in Light of COVID-19 Pandemic. Higher Education Studies, 10(3), 16-25. https://eric.ed.gov ? $\mathrm{q}=\mathrm{ict}+$ covid $+19 \& \mathrm{id}=\mathrm{EJ} 1259642$. https://doi.org/10.5539/hes.v10n3p16

[4] Almalki, A. (2020). Integration of Technology among Saudi EFL Teachers. English Language Teaching, 13(8), 160-167. https://doi.org/10.5539/elt.v13n8p160

[5] Angeli, C., \& Valanides, N. (2009). Epistemological and methodological issues for the conceptualization, development, and assessment of ICT-TPCK: Advances in technological pedagogical content knowledge (TPCK). Computers and Education, 52(1), 154-168. https:// doi.org/10.1016/j.compedu.2008.07.006

[6] Baillie, C., \& Percoco, G. (2000). A study of present use and usefulness of computer-based learning at a technical university. European Journal of Engineering Education, 25(1), 33-43. https://doi.org/10.1080/030437900308625

[7] Bayu, D. (2020). Mengenal Apa Itu New Normal di Tengah Pandemi Corona. Kompas.Com. https://www.kompas.com/tren/read/2020/05/20/063100865/mengenal-apa-itu-new-normaldi-tengah-pandemi-corona-?page $=2$

[8] Cahyadi, A. (2020). COVID-19 Outbreak and New Normal Teaching in Higher Education: Empirical Resolve from Islamic Universities in Indonesia. Dinamika Ilmu, 20(2), 255-266. https://eric.ed.gov/?q=ict+covid+19\&ff1=locIndonesia\&id=EJ1274095. https:// doi.org/10.21093/di.v20i2.2545

[9] Ceylan, V. K., \& Kesici, A. E. (2017). Effect of Blended Learning to Academic Achievement. Journal of Human Science, 14(1), 308-320. https://eric.ed.gov/?q=achievement+and+ blended+learning \&ft=on\&ff1=dtySince 2016\&id=ED593345. https://doi.org $/ 10.14687 /$ ihs.v14i1.4141

[10] Chai, C. S., Koh, J. H. L., \& Tsai, C. C. (2013). A review of technological pedagogical content knowledge. Educational Technology and Society, 16(2), 31-51.

[11] Dinc, E. (2019). Prospective Teachers' Perceptions of Barriers to Technology Integration in Education. Contemporary Educational Technology, 10(4), 381-398. https://doi. org/10.30935/cet.634187

[12] Dinç, E. (2017). Differentiated learning environment - A classroom for Quadratic Equation, function and Graphs. 14th International Conference on Cognition and Exploratory Learning in the Digital Age, CELDA 2017, 237-240.

[13] Firat Altay, İ., \& Altay, A. (2019). A Review of Studies on Blended Learning in EFL Environment conditions of the Creative Commons Attribution license (CC BY-NC-ND). International Journal of Curriculum and Instruction, 11(1), 125-140.

[14] Godwin-Jones, R. (2017). Smartphones and Language Learning. Language Learning \& Technology, 21(2), 3-17.

[15] Hardisky, M. (2018). TPACK: Technology Integration and Teacher Perceptions. https://eric. ed.gov/?q=tpack\&id=ED585352

[16] Harrell, S., \& Bynum, Y. (2018). Factors Affecting Technology Integration in the Classroom. 
[17] Hero, J. L. (2019). The Impact of Technology Integration in Teaching Performance. International Journal of Sciences: Basic and Applied Research (IJSBAR) International Journal of Sciences: Basic and Applied Research, 48(1), 101-114. http://gssrr.org/index. php?journal=JournalOfBasicAndApplied

[18] Hidayat, M. W. (2017, July 4). 10 Negara dengan Pertumbuhan e-Learning Tertinggi di Dunia - Tekno Liputan6.com. Tech News. https://www.liputan6.com/tekno/ read/3010481/10-negara-dengan-pertumbuhan-e-learning-tertinggi-di-dunia

[19] Hossein Keshavarz, M., \& Hulus, A. (2019). The Effect of Students' Personality and Learning Styles on Their Motivation for Using Blended Learning. Advances in Language and Literary Studies, 10(6), 78-88. https://doi.org/10.7575/aiac.alls.v.10n.6p.78

[20] Hur, J. W., Shannon, D., \& Wolf, S. (2016). An Investigation of Relationships Between Internal and External Factors Affecting Technology Integration in Classrooms. Journal of Digital Learning in Teacher Education, 32(3), 105-114. https://doi.org/10.1080/21532974. 2016.1169959

[21] Isiguzel, B., \& Hacı Bektas, N. (2014). The Blended Learning Environment on the Foreign Language Learning Process: A Balance for Motivation and Achievement. Turkish Online Journal of Distance Education, 15(3), 108-121. https://doi.org/10.17718/tojde.41051

[22] Islam, M. Sirajul, \& Grönlund, Å. (2016). An international literature review of 1:1 computing in schools. Journal of Educational Change, 17(2), 191-222. https://doi.org/10.1007/ s10833-016-9271-y

[23] Islam, Md Sadequle. (2019). Bangladeshi University Students' Perception on Using Google Classroom for Teaching English. International Journal of Psycho-Educational Sciences, $8(2), 57-65$.

[24] Kastner, J. A. (2020). Blended Learning: Moving beyond the Thread Quality of Blended Learning and Instructor Experiences. Journal of Educators Online, 17(2).

[25] Khalitova, L., \& Gimaletdinova, G. (2016). Mobile Technologies in Teaching English as a Foreign Language in Higher Education: A Case Study of Using Mobile Application Instagram. ICERI2016 Proceedings, 1, 6155-6161. https://doi.org/10.21125/iceri.2016.0395

[26] Kilinc, E., Tarman, B., \& Aydin, H. (2018). Examining Turkish Social Studies Teachers' Beliefs about Barriers to Technology Integration. TechTrends, 62(3), 221-223. https://doi. org/10.1007/s11528-018-0280-y

[27] Kimmons, R., \& Hall, C. (2016). Toward a Broader Understanding of Teacher Technology Integration Beliefs and Values. Jl. of Technology and Teacher Education, 24(3), 309-335.

[28] Koehler, M. J., \& Mishra, P. (2005). What happens when teachers design educational technology? The development of Technological Pedagogical Content Knowledge. Journal of Educational Computing Research, 32(2), 131-152. https://doi. org/10.2190/0EW7-01WB-BKHL-QDYV

[29] Lembani, R., Gunter, A., Breines, M., \& Dalu, M. T. B. (2020). The same course, different access: the digital divide between urban and rural distance education students in South Africa. Journal of Geography in Higher Education, 44(1), 70-84. https://doi.org/10.1080/0 $\underline{3098265.2019 .1694876}$

[30] Mahdum, H., \& Safriyanti, M. (2019). Exploring Teacher Perceptions and Motivations to ICT Use in Learning Activities in Indonesia. Journal of Information Technology Education Research, 18, 293-317. https://eric.ed.gov/?q=ict+in+rural+area\&id=EJ1218937. https:// doi.org/10.28945/4366

[31] Mailizar, M., \& Fan, L. (2020). Indonesian Teachers' Knowledge of ICT and the Use of ICT in Secondary Mathematics Teaching. EURASIA Journal of Mathematics, Science and Technology Education, 16(1), 1-13. https://doi.org/10.29333/ejmste/110352

[32] Mali, Y. C. G. (2016). Integrating Technology in Indonesian EFL fClassrooms: Why Not? Beyound Words, 4(1), 17-26. 
[33] N.M.S, M., \& I.G.A.L.P, U. (2020). English Learning with Powtoon Animation Video. Journal of Education Technology, 4(2), 110-119. https://doi.org/10.23887/jet.v4i2.25096

[34] Nguyen, T. N., Philipsen, B., Muls, J., Wang, R., \& Lombaerts, K. (2018). Motivation and Barriers for University Teachers to Apply Blended Learning in Language Classes. Journal of English as an International Language, 13(2), 81-99. https://eric. ed.gov/?q=motivation + and + blended + learning \& ft=on\&id=EJ1247032

[35] Önalan, O., \& Kurt, G. (2020). Exploring Turkish EFL teachers' perceptions of the factors affecting technology integration: A case study. Journal of Language and Linguistic Studies, 16(2), 626-646. https://doi.org/10.17263/j1ls.759264

[36] Ozden, S., \& Izmirli-Omer, K. (2017). New Barriers to Technology Integration. Eurasian Journal of Educational Research, 72, 147-166. https://doi.org/10.14689/ejer.2017.72.8

[37] Pourhosein Gilakjani, A., \& Sabouri, N. B. (2017). Advantages of Using Computer in Teaching English Pronunciation. International Journal of Research in English Education, 2(3), 78-85. https://doi.org/10.18869/acadpub.ijree.2.3.78

[38] Prasojo, L. D., Habibi, A., Yaakob, M. F. M., Mukminin, A., Haswindy, S., \& Sofwan, M. (2019). An explanatory sequential study on Indonesian principals' perceptions on ICT integration barriers. Electronic Journal of E-Learning, 17(1), 1-10.

[39] Raja, R., \& Nagasubramani, P. C. (2018). Impact of modern technology in education. India Journal of Applied and Advanced Research, 2018(3), 33-35. https://doi.org/10.21839/ jaar.2018.v3iS1.165

[40] Ratminingsih, N. M., Artini, L. P., \& Padmadewi, N. N. (2017). Incorporating self and peer assessment in reflective teaching practices. International Journal of Instruction, 10(4), 165-184. https://doi.org/10.12973/iji.2017.10410a

[41] Khan, N., \& Qureshi, M. I. (2020). A systematic literature review on online medical services in Malaysia. International Journal of Online and Biomedical Engineering, 16(6), 107-118. https://doi.org/10.3991/ijoe.v16i06.13573

[42] Mustapha, I., Van, N. T., Shahverdi, M., Qureshi, M. I., \& Khan, N. (2021). Effectiveness of Digital Technology in Education during COVID-19 Pandemic. A Bibliometric Analysis. International Journal of Interactive Mobile Technologies, 15(8), 136-154. https://doi. org/10.3991/ijim.v15i08.20415

[43] Qureshi, M. I., Khan, N., Ahmad Hassan Gillani, S. M., \& Raza, H. (2020). A systematic review of past decade of mobile learning: What we learned and where to go. International Journal of Interactive Mobile Technologies, 14(6), 67-81. https://doi.org/10.3991/ijim. v14i06.13479

[44] Rosenberg, M. G., \& An, Y. (2019). Supporting Science Teachers' Learner-Centered Technology Integration through Situated Mentoring. Educational Process International Journal, 8(4), 248-263. https://doi.org/10.22521/edupij.2019.84.4

[45] Rusmiati Aliyyah, R., Rachmadtullah, R., Samsudin, A., Syaodih, E., Nurtanto, M., \& Riana Suryanti Tambunan, A. (2020). The Perceptions of Primary School Teachers of Online Learning during the COVID-19 Pandemic Period: A Case Study in Indonesia. Journal of Ethnic and Cultural Studies, 2020(2), 90-109. https://doi.org/10.29333/ejecs/388

[46] Sari, F. M., \& Wahyudin, A. Y. (2019). Undergraduate Students' Perceptions toward Blended Learning through Instagram in English for Business Class. International Journal of Language Education, 3(1), 64-73. https://doi.org/10.26858/ijole.v1i1.7064

[47] Shulman, L. S. (1986). Those Who Understand: Knowledge Growth in Teaching. Educational Researcher, 15(2), 4-14. https://doi.org/10.3102/0013189X015002004

[48] Simbolon, N., Simanjuntak, E. B., Simanjuntak, M. P., \& Purba, J. T. (2020). The Effectiveness of ICT-based Learning in Improving English Skills of Elementary School Teacher College Students. Academic Journal of Interdisciplinary Studies, 9(5), 217-226. https://doi. org/10.36941/ajis-2020-0099 
[49] Spraakman, G., O’Grady, W., Askarany, D., \& Akroyd, C. (2015). Employers' Perceptions of Information Technology Competency Requirements for Management Accounting Graduates. Accounting Education, 24(5), 403-422. https://doi.org/10.1080/09639284.2015.1089177

[50] Sujannah, W. D., Cahyono, Y., \& Astuti, U. P. (2020). Effect of Blended Learning Using Google Classroom on Writing Ability of EFL Students across Autonomy Levels. Teaching English with Technology, 20(2), 82-97. http://www.tewtjournal.org

[51] Thompson, A. D., \& Mishra, P. (2007). Breaking News: TPCK becomes TPACK! Journal of Computing in Teacher Education, 24(2), 38-64.

[52] van der Spoel, I., Noroozi, O., Schuurink, E., \& van Ginkel, S. (2020). Teachers' online teaching expectations and experiences during the Covid19-pandemic in the Netherlands. European Journal of Teacher Education, 43(4), 623-638. https://doi.org/10.1080/02619768 .2020 .1821185

\section{Authors}

Mister Gidion Maru, English Education Department, Universitas Negeri Manado. E-mail: mrgidionmaru@unima.ac.id.

Chris Caesar Pikirang, Postgraduate, Universitas Negeri Manado. E-mail: Pikirangchris68@gmail.com.

Donal M Ratu, English Education Deparment, Universitas Negeri Manado. E-mail: Donalratu73@gmail.com.

Jim Ronny Tuna, English Education Department, Universitas Negeri Manado. E-mail:.jrtuna@unima.ac.id.

Article submitted 2021-07-15. Resubmitted 2021-08-26. Final acceptance 2021-08-26. Final version published as submitted by the authors. 